\title{
EFFECT OF SOIL MOISTURE DEPLETION AND MULCHING OF CV. ZAGHLOUL DATE PALM (Phoenix dactylifera L.) FRUITING UNDER DESERT CONDITIONS. \\ El-Kosary, S. ${ }^{1}$; E. I. Bakr'; I. A. Hussein ${ }^{2}$ and Sheren A. Abdelhameed ${ }^{2}$ \\ 1- Pomology Department, Fac. Agric. Cairo Univ. Giza, Egypt \\ 2- Desert Res. Cent., Pomology Unit, Mataria, Cairo, Egypt.
}

\begin{abstract}
This investigation was conducted during two successive seasons (2005 and 2006) at El Sheikh Zuwayid Experimental Station Desert Research Center, North Sinai Governorate. It is aimed to study the effect of soil moisture depletion and mulching of $\mathrm{cv}$. Zaghloul date palm under desert conditions using three soil moisture depletion (25, 50 and $75 \%$ ) from available water. Also, four mulching treatments, Plant cover (T1) using Oregano plants (Origanum syriacum L.), Plastic sheet (T2), Gravels cover (T3) and uncovered (T4) (control). All treatments were irrigated by drip irrigation system using bubbler (200l/h). The selected palms under investigation were similar in vigor, aged 15 years and subjected to the recommended orchard managements. The obtained results showed that soil moisture depletion at $25 \%$ produced the highest fruit set percentage and total yield. On the other hand, soil moisture depletion at $75 \%$ raised fruit characters (length, diameter, size, weight, bulb, TSS and sugars). Concerning mulching treatments, plastic cover (T2) had enhanced the fruit characteristics and saved the applied water than the other mulching treatments. In this respect, the interaction between depletion and mulching treatments, indicated that depletion at $75 \%$ with plastic cover was the best treatment casing the superiority of fruit characteristics and saving of applied water.
\end{abstract}

Keywords: Date palm - Cultivar - Zaghloul - Irrigation - Depletion - Moisture Mulching.

\section{INTRODUCTION}

Date palm (Phoenix dactylifera L.) needs sufficient water of acceptable quality to reach its potential yield. However, desert soils suffer mainly from the shortage in water. So, several soil management practices are adopted to restrict water losses and to maximize the output of limited water resources. One of the most important and effective measure for controlling soil water and improving thermal regime is soil mulching. Estimation of evapotranspiration is important for irrigation planning and management of date palm orchards. Many researchers reported that improper irrigation practices were the main factors for small size, poor growth and early ripening of date palm fruits (Furr and Armstrong, 1956; Hussein and Hussein, 1983; El-Romah and Kassem, 1989; Kashani, 1990; Al-Amoud et al., 2000; Amiri, 2003; Al-Wasel et al., 2007; Amiri et al., 2007). Deep watering on a regular basis is vital to good growth of date palm trees (Amiri et al., 2007). Modern irrigation system such as sprinklers and drip bubbler system are used in different countries. The bubbler irrigation technique seemed to be promising for use in the arid and semi-arid areas, since water usage is more efficient, 
and the small output might prevent a sudden rise in the water table, as compared with other irrigation methods, such as basin or sprinkler irrigation (Hussein and Hussein, 1983; Jain and Pareek, 1989; Mohamed and Khemaies, 1998; Norman et al., 1998; Amiri, 2003; Alihouri, 2007; Sayed et al., 2007 and Shaheen, 2007). Thus, it is anticipated that a considerable amount of water will be saved as result from converting the traditional irrigation systems into the modern methods. Hussain et al. (1993) and Nassar et al. (2003) suggested that irrigation of date palm tree should be carried out at $40-60 \%$ depletion of total water available at capacity to saving water with good fruit quality and palm growth. In Addition, many workers reported that mulching increased growth, yield and fruit characteristics (El-Mardi et al., 2007 on Khalas palm; Mohanty et al., 2002 and Shirgure et al., 2003 on mandarin, and Ghosh and Bauri, 2003 on mango.

The information on water use, irrigation scheduling and management regarding date palm tree is limited. Therefore, the present investigation is aimed to study the effect of soil moisture depletion and mulching on yield and fruit characteristics of Zaghloul date palm trees under desert conditions; aiming to increase the water uses efficiency due to shortage in water under arid conditions.

\section{MATERLALS AND METHODS}

This study was conducted during two successive seasons (2005 and 2006) at El-Sheikh Zuwayid Experimental Station, Desert Research Center, about $35 \mathrm{~km}$ east of El-Arish city, North Sinai Governorate, Egypt. This study is aimed to study the effect of soil moisture depletion and mulching on fruit production of Zaghloul date palm cultivar. The saline ground water, which used in this study, was $4.84 \mathrm{ds} / \mathrm{m}$ (Table, 1).

Table 1. Irrigation water analysis

\begin{tabular}{|c|c|c|c|c|c|c|c|}
\hline \multirow{2}{*}{\multicolumn{2}{|c|}{ Measurements }} & \multicolumn{6}{|c|}{ Season } \\
\hline & & \multicolumn{3}{|c|}{ Winter } & \multicolumn{3}{|c|}{ summer } \\
\hline \multicolumn{2}{|c|}{$\mathrm{pH}$} & \multicolumn{3}{|c|}{7.8} & \multicolumn{3}{|c|}{7.6} \\
\hline \multicolumn{2}{|l|}{\begin{tabular}{|ll}
$\mathrm{EC}$ & $(\mathrm{ds} / \mathrm{m})$
\end{tabular}} & \multicolumn{3}{|c|}{4.84} & \multicolumn{3}{|c|}{5.06} \\
\hline \multicolumn{2}{|l|}{ SAR } & \multicolumn{3}{|c|}{16.55} & \multicolumn{3}{|c|}{9.45} \\
\hline \multicolumn{2}{|l|}{ RSC (me/l) } & \multicolumn{3}{|c|}{-4.82} & \multicolumn{3}{|c|}{-18.92} \\
\hline \multicolumn{2}{|l|}{ TDS (ppm) } & \multicolumn{3}{|c|}{2920} & \multicolumn{3}{|c|}{3161} \\
\hline \multicolumn{2}{|l|}{ Units } & Ppm & Epm & $\%$ & Ppm & Epm & $\%$ \\
\hline \multirow{4}{*}{ Soluble cations } & $\mathrm{Ca}^{++}$ & 88.88 & 4.44 & 9.00 & 215.70 & 10.76 & 20.53 \\
\hline & $\mathrm{Mg}^{++}$ & 76.08 & 6.26 & 12.71 & 128.64 & 10.58 & 20.19 \\
\hline & $\mathrm{Na}^{+}$ & 880.0 & 38.26 & 77.67 & 710.0 & 30.87 & 58.89 \\
\hline & $\mathrm{K}^{+}$ & 12.0 & 0.31 & 0.62 & 8.0 & 0.20 & 0.39 \\
\hline \multicolumn{2}{|l|}{ Total } & 1057.0 & 49.26 & 100.0 & 1062.3 & 52.42 & 100.0 \\
\hline \multirow{4}{*}{ Soluble anions } & $\mathrm{CO}_{3}^{--}$ & 0.0 & 0.0 & 0.0 & 0.0 & 0.0 & 0.0 \\
\hline & $\mathrm{HCO}_{3}{ }^{-}$ & 358.2 & 5.87 & 12.05 & 148.23 & 2.43 & 4.48 \\
\hline & $\mathrm{SO}_{4}^{-}$ & 625.0 & 13.01 & 26.70 & 725.0 & 15.09 & 27.86 \\
\hline & $\mathrm{Cl}^{-}$ & 1059.0 & 29.86 & 61.26 & 1300.0 & 36.66 & 67.66 \\
\hline \multicolumn{2}{|l|}{ Total } & 1863.0 & 48.74 & 100.0 & 2099.0 & 54.19 & 100.0 \\
\hline \multicolumn{2}{|l|}{ Class } & & $\mathrm{C}_{5} \mathrm{~S}_{4}$ & & \multicolumn{3}{|c|}{$\mathrm{C}_{5} \mathrm{~S}_{4}$} \\
\hline
\end{tabular}

SAR = Sodium adsorption ratio, $\mathrm{RSC}=$ residual sodium carbon., TDS = Total dissolved solids, emp = equivalent per million. 
Moisture content in the soil was measured by Neutron moisture range (Neutron Probe). A meteorological station is located inside the experimental field, whose altitude is about 15 meters above sea level, at latitude $31 \circ .08 \mathrm{~N}$ and longitude $34.01 \mathrm{E}$., the meteorological data for the two seasons were used to compute potential evapotranspiration (ETo) rates using the Penmam Monteith equation (Table 2).

Table 2. Meteorological data of El-Sheikh Zuwayid region, north Sinai during 2005 and 2006 seasons

\begin{tabular}{|c|c|c|c|c|c|c|c|c|c|c|c|c|}
\hline \multirow[t]{2}{*}{ 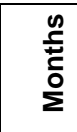 } & \multicolumn{2}{|c|}{$\begin{array}{l}\text { Wind speed } \\
(\mathrm{km} / \mathrm{h})\end{array}$} & \multicolumn{2}{|c|}{$\begin{array}{l}\text { Air temp. } \\
\text { (C) }\end{array}$} & \multicolumn{2}{|c|}{$\begin{array}{l}\text { Avg. relative } \\
\text { humidity (\%) }\end{array}$} & \multicolumn{2}{|c|}{$\begin{array}{l}\text { Rain (mm } \\
\text { /month) }\end{array}$} & \multicolumn{2}{|c|}{$\begin{array}{c}\text { Actual } \\
\text { sunshine } \\
\left(\mathrm{w} / \mathrm{m}^{2}\right)\end{array}$} & \multicolumn{2}{|c|}{$\begin{array}{c}\text { Eto (mm/ } \\
\text { Day) }\end{array}$} \\
\hline & 2005 & 2006 & 2005 & 2006 & 2005 & 2006 & 2005 & 2006 & 2005 & 2006 & 2005 & 2006 \\
\hline Jan. & 9.9 & 7.86 & 14.1 & 12.0 & 79.5 & 86.6 & 33.0 & 53.5 & 2.34 & 2.29 & 1.71 & \begin{tabular}{|l}
1.47 \\
\end{tabular} \\
\hline Feb. & 11.7 & 8.81 & 14.3 & 12.4 & 88.6 & & 29.2 & 38.8 & 2.95 & 2.71 & 2.38 & 2.01 \\
\hline Mar. & 9.81 & 5.31 & 17.5 & 14.8 & 81.5 & 88.0 & 19.0 & 28.7 & 5.27 & 4.67 & 2.85 & 2.71 \\
\hline Apr. & 8 & & & & & & & & .78 & 5.73 & 77 & 3.57 \\
\hline May. & \begin{tabular}{|l|}
7.07 \\
\end{tabular} & 3.78 & 21.6 & 19.1 & 85.5 & 91.4 & 0.50 & 0 & 7.48 & 7.71 & 5.51 & 3.86 \\
\hline June. & 3.32 & 2.40 & 24.2 & 22.5 & 92.9 & 94.2 & 0 & 0 & 8.83 & 7.78 & 5.85 & 4.15 \\
\hline July. & 4.39 & 2.88 & 26.7 & 24.7 & 94.6 & 6 & 0 & 0 & 8.75 & 7.49 & 5.70 & 4.66 \\
\hline Aug. & 4.79 & 1.84 & 27.6 & 25.7 & 91.9 & 94.9 & 0 & 0 & 7.72 & 6.04 & 5.32 & 4.19 \\
\hline Sep. & 2.46 & 1.98 & 26.2 & 25.6 & 88.5 & 91.1 & 0 & 1.02 & 5.37 & 4.43 & 4.85 & 3.42 \\
\hline Oct. & 1.78 & 4.30 & 24.3 & 21.4 & 95.2 & 88.1 & 0.76 & 0 & 2.97 & 2.62 & 3.23 & 2.94 \\
\hline Nov. & 12.92 & 5.67 & 19.9 & 16.6 & 90.1 & 86.8 & 75.9 & 22.8 & 2.00 & 2.01 & 2.19 & 1.70 \\
\hline Dec. & 5.23 & 6.84 & 15.1 & 14.2 & 88.4 & 95.0 & \begin{tabular}{|c|}
99.3 \\
\end{tabular} & 27.1 & 2.04 & 1.70 & 1.62 & 1.56 \\
\hline Avg. & 6.83 & 4.88 & 20.6 & 18.8 & 88.5 & 90.6 & $258^{*}$ & $174^{*}$ & 5.21 & 4.60 & 3.81 & 3.02 \\
\hline
\end{tabular}

This investigation had 36 palms of fruiting Zaghloul date palm cultivar. The palms were similar in growth and age. (15 years old). They were pruned at 8:1 leaf /bunch ratio (El-Salhy, 2001). They were pollinated by the same source of pollen grains just at the fourth day from cracking in both seasons. Pollination was done at April month during the two seasons of study. All palms were subjected to the normal orchard management (100 $\mathrm{kg} /$ palm organic manure, $7 \mathrm{~kg} / \mathrm{palm}$ Ammonium sulfate, $4 \mathrm{~kg} / \mathrm{palm}$ potassium sulfate and $2.5 \mathrm{~kg} /$ palm super phosphate). Nine bunches were left on each palm. Three soil moisture depletion; were applied $25 \%, 50 \%$, and $75 \%$ from available water on 12 palm trees for each. The individual treatments of depletion were belted by 7 meters a part between each depletion. Also, four mulching treatments were done as follows $T_{1}$ : plant cover using oregano plants (Origanum syriacum L. Subsp. Sinaicum) that planted around the palms on a circular area $4 \mathrm{~m}$ a part. Oregano plant has a fiber roots reach 15 $\mathrm{cm}$ depth, the water requirements was about $0.7 \mathrm{~m}^{3} / \mathrm{year}$, this amount

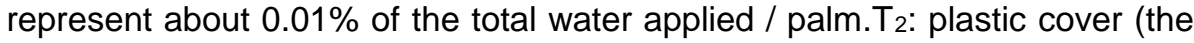
soil around the tree was covered by plastic on a circular area $4 \mathrm{~m}$ a part), $\mathrm{T}_{3}$ : gravels cover (the soil around the tree was covered by gravels on a circular area, $4 \mathrm{~m}$ ) and $\mathrm{T}_{4}$ : control treatment (normal sandy soil).

The individual treatment contained three palms, each is considered as a replicate. All treatments were irrigated by drip irrigation system using bubbler $(200 \mathrm{~L} / \mathrm{hr})$. The yield of fruits for this experiment was harvested at the third week of September (full color stage) in both seasons. 
The following data were recorded:

1- Total yield was estimated as average weights of bunches per palm $(\mathrm{Kg})$.

2- Fruit set percentage was calculated at harvest using this equation: Total number of retained fruits per bunch

Fruit retained $=$ $\mathrm{X} 100$

Total scares number per bunch

3- Fruit physical properties: Samples were taken from four replicates, each replicate of 20 fruits taken randomly from each bunch to determine fruit weight, flesh weight, fruit dimensions (length and diameter) and fruit size.

4- Fruit moisture content percentage was calculated as described in A.O.A.C. (1995).

5- Total soluble solids content (TSS) percentage was determined in juice fruit as described in A.O.A.C. (1995).

6- Fruit acidity percentage was determined as described in A.O.A.C. (1995) and the titratable acidity was calculated as citric acid (Ranganna, 1979).

7- Total soluble sugars were determined according to Smith et al. (1956) in the methanol extract using the phenol sulfuric acid method and the concentration was calculated as $\mathrm{g} / 100 \mathrm{~g}$ dry weight of fruits.

8- Reducing soluble sugars were determined in the methanol extract according to Nelson and Somogy (1944) as described in A.O.A.C. (1995) and the percentage was calculated as $\mathrm{g} / 100 \mathrm{~g}$ dry weight of fruits.

9- Tannins content was determined as described in A. O. A. C (1995) and concentration was calculated as $\mathrm{g} / 100 \mathrm{~g}$ fresh pulp weight according to the following equation: $1 \mathrm{ml}$. Oxalic acid $(0.1 \mathrm{~N}$. $)=0.0416 \mathrm{~g}$. tannins.

10- Total applied irrigation water and number of irrigation: the number of irrigation was estimated and the total applied irrigation water were calculated for each treatment according to the following equation:

Total applied irrigation water $=$ number $\mathrm{X}$ Period $($ Table 3$) \mathrm{X}$ discharge of irrigation system .

11- Water use efficiency $\left(\mathrm{Kg} / \mathrm{m}^{3}\right)$ was calculated according to James (1988) using the following equation:

Water use efficiency =

$$
\text { Yield per palm (kg) }
$$

Total applied water $\left(\mathrm{m}^{3} /\right.$ palm)

Table 3. Period of applied water irrigation (min.) at different soil moisture depletion for two seasons

\begin{tabular}{|c|c|c|}
\hline $\begin{array}{c}\text { Soil moisture } \\
\text { Depletion }\end{array}$ & $\begin{array}{c}\text { Season } \\
\mathbf{2 0 0 5}\end{array}$ & $\begin{array}{c}\text { Season } \\
\mathbf{2 0 0 6}\end{array}$ \\
\hline $25 \%$ & 60 & 50 \\
\hline $50 \%$ & 90 & 75 \\
\hline $75 \%$ & 120 & 100 \\
\hline
\end{tabular}

\section{Statistical analysis}

The obtained data was subjected to analysis of variance. The mean values were compared using LSD method at $5 \%$ level. The data were tabulated and statistically analyzed according to the split plot design which depletion was in main plot and mulch in sub plot (Snedecor and Cochran, 1989). The percentages were transformed to the arcsine to find the binomial percentages according to (Steel and Torrie, 1980). 


\section{RESULTS NAD DISUSSION}

\section{Fruit set percentage and total yield:}

Data presented in Table 4 revealed that fruit set and total yield per palm were significantly affected by soil moisture depletion in both seasons. Soil moisture depletion at $25 \%$ recorded the highest fruit set percentage and total yield in the two seasons. It was clearly noticed that $25 \%$ depletion was followed by soil moisture depletion at $50 \%$ and $75 \%$ of fruit set percentages and total yields per palm in both seasons, respectively. In addition, there is no differences were observed between $50 \%$ and $75 \%$ depletion on fruit set and total yield in both seasons. On the other hand, soil mulching treatments significantly affected the fruit set\% and total yield in both seasons. Plastic cover $\left(T_{2}\right)$ had the highest ability promotion to increase fruit set percentage and total yield comparing with other soil mulching treatments used. The highest fruit set percentage and total yield were recorded with $T_{2}$ (plastic cover) followed by $\mathrm{T}_{1}$ (plant cover), $\mathrm{T}_{3}$ (gravel cover) and $\mathrm{T}_{4}$ (control treatment) in both seasons, respectively.

Table 4. Effect of soil moisture depletion and soil mulching treatments on fruit set (\%) and total yield / palm (kg) for Zaghloul date palm cv. during 2005 and 2006 seasons.

\begin{tabular}{|c|c|c|c|c|c|}
\hline \multirow{2}{*}{\multicolumn{2}{|c|}{\begin{tabular}{|c|} 
Treatments \\
\end{tabular}}} & \multicolumn{2}{|c|}{ Fruit set (\%) } & \multicolumn{2}{|c|}{ Total yield palm ( $\mathrm{kg}$ ) } \\
\hline & & 2005 & 2006 & 2005 & 2006 \\
\hline \multicolumn{6}{|c|}{ Soil moisture depletion } \\
\hline \multicolumn{2}{|l|}{$25 \%$} & 27.92 & 27.72 & 122.73 & 122.58 \\
\hline \multicolumn{2}{|l|}{$50 \%$} & 23.82 & 23.50 & 120.15 & 119.65 \\
\hline \multicolumn{2}{|l|}{$75 \%$} & 23.29 & 22.96 & 119.08 & 118.60 \\
\hline \multicolumn{2}{|c|}{ LSD at 0.05} & 2.79 & 1.43 & 1.38 & 2.77 \\
\hline \multicolumn{6}{|c|}{ Soil mulching treatments* } \\
\hline \multicolumn{2}{|l|}{$\mathrm{T}_{1}$} & 24.95 & 24.67 & 121.20 & 120.63 \\
\hline \multicolumn{2}{|l|}{$\mathrm{T}_{2}$} & 26.77 & 26.71 & 121.87 & 121.53 \\
\hline \multicolumn{2}{|l|}{$\mathrm{T}_{3}$} & 23.90 & 23.46 & 119.67 & 119.47 \\
\hline \multicolumn{2}{|l|}{$\mathrm{T}_{4}$} & 24.41 & 24.08 & 119.87 & 119.47 \\
\hline \multicolumn{2}{|c|}{ LSD at 0.05} & 1.08 & 0.92 & 0.90 & 1.34 \\
\hline \multicolumn{6}{|c|}{ Interactions } \\
\hline \multirow{4}{*}{$25 \%$} & $\mathrm{~T}_{1}$ & 28.65 & 28.52 & 123.50 & 123.40 \\
\hline & $\mathrm{T}_{2}$ & 29.35 & 29.21 & 124.80 & 124.60 \\
\hline & $\mathrm{T}_{3}$ & 27.34 & 27.15 & 122.20 & 122.00 \\
\hline & $\mathrm{T}_{4}$ & 26.33 & 26.00 & 120.40 & 120.30 \\
\hline \multirow{4}{*}{$50 \%$} & $\mathrm{~T}_{1}$ & 23.55 & 23.51 & 121.40 & 120.60 \\
\hline & $\mathrm{T}_{2}$ & 25.44 & 25.25 & 120.50 & 119.90 \\
\hline & $\mathrm{T}_{3}$ & 22.79 & 22.00 & 119.20 & 119.10 \\
\hline & $\mathrm{T}_{4}$ & 23.50 & 23.24 & 119.50 & 119.00 \\
\hline \multirow{4}{*}{$75 \%$} & $\mathrm{~T}_{1}$ & 22.66 & 21.98 & 118.70 & 117.90 \\
\hline & $\mathrm{T}_{2}$ & 25.52 & 25.66 & 120.30 & 120.10 \\
\hline & $\mathrm{T}_{3}$ & 21.58 & 21.22 & 117.60 & 117.30 \\
\hline & $\mathrm{T}_{4}$ & 23.40 & 23.00 & 119.70 & 119.10 \\
\hline \multicolumn{2}{|c|}{ LSD at 0.05} & 1.87 & 1.59 & 1.56 & 2.33 \\
\hline
\end{tabular}

${ }^{*} \mathrm{~T}_{1}$ : Plant cover, $\mathrm{T}_{2}$ : Plastic cover, $\mathrm{T}_{3}$ : Gravel cover and $\mathrm{T}_{4:}$ Control (without any cover).

Furthermore, the fruit set and total yield were varied significantly as influenced by the interaction between soil moisture depletion and soil mulching treatments. $\mathrm{T}_{2}$ at $25 \%$ soil moisture depletion gave the highest fruit 
set and total yield comparing with other interactions in both seasons. On the other hand, $\mathrm{T}_{3}$ (gravel cover) at $75 \%$ soil moisture depletion showed the lowest fruit set percentage and total yield in both seasons.

Generally, these results are in agreement with results mentioned by Alihouri (2007), who recorded that the highest yield was obtained by irrigation after $50 \mathrm{~mm}$ evaporation from pan. Moreover, El-Mardi et al. (2007) mentioned that Khalas and Khasab date cultivars were mulched with date palm fiber. They found that mulched palms had the highest total yield comparing with untreated ones.

\section{Zaghloul fruit length, diameter and size:}

Concerning the results in Table 5, Zaghloul fruit length, diameter and size were significantly affected by soil moisture depletion in both seasons. Soil moisture depletion at $75 \%$ recorded an increase in fruit length, diameter and size as compared with the soil moisture depletion at 50\%, 25\% in descending order in both seasons.

Table 5. Effect of soil moisture depletion and soil mulching treatments on fruit length $(\mathrm{cm})$, diameter $(\mathrm{cm})$ and size $\left(\mathrm{cm}^{3}\right)$ of Zaghloul date palm during 2005 and 2006 seasons.

\begin{tabular}{|c|c|c|c|c|c|c|c|}
\hline \multirow{2}{*}{\multicolumn{2}{|c|}{ Treatments }} & \multicolumn{2}{|c|}{ Fruit length (cm) } & \multicolumn{2}{|c|}{ Fruit diameter $(\mathrm{cm})$} & \multicolumn{2}{|c|}{ Fruit size $\left(\mathrm{cm}^{3}\right)$} \\
\hline & & 2005 & 2006 & 2005 & 2006 & 2005 & 2006 \\
\hline \multicolumn{8}{|c|}{ Soil moisture depletion } \\
\hline \multicolumn{2}{|c|}{$25 \%$} & 4.56 & 4.67 & 2.45 & 2.64 & 19.70 & 19.26 \\
\hline \multicolumn{2}{|l|}{$50 \%$} & 5.25 & 5.50 & 2.87 & 3.06 & 22.44 & 23.01 \\
\hline \multicolumn{2}{|l|}{$75 \%$} & 5.70 & 5.81 & 3.29 & 3.40 & 24.78 & 25.90 \\
\hline \multicolumn{2}{|c|}{ LSD at 0.05} & 0.39 & 0.09 & 0.10 & 0.11 & 1.12 & 1.13 \\
\hline \multicolumn{8}{|c|}{ Soil mulching treatments* } \\
\hline \multicolumn{2}{|l|}{$\mathrm{T}_{1}$} & 5.25 & 5.40 & 3.02 & 3.09 & 22.62 & 23.10 \\
\hline \multicolumn{2}{|l|}{$\mathrm{T}_{2}$} & 5.67 & 5.82 & 3.17 & 3.39 & 25.07 & 25.54 \\
\hline \multicolumn{2}{|l|}{$\mathrm{T}_{3}$} & 5.03 & 5.15 & 2.68 & 2.90 & 21.06 & 21.40 \\
\hline \multicolumn{2}{|l|}{$\mathrm{T}_{4}$} & 4.72 & 4.92 & 2.60 & 2.76 & 20.46 & 20.86 \\
\hline \multicolumn{2}{|c|}{ LSD at 0.05} & 0.24 & 0.21 & 0.12 & 0.07 & 1.04 & 1.04 \\
\hline \multicolumn{8}{|c|}{\begin{tabular}{|l} 
Interactions \\
\end{tabular}} \\
\hline \multirow{4}{*}{$25 \%$} & $\mathrm{~T}_{1}$ & 4.30 & 4.44 & 2.40 & 2.47 & 18.24 & 18.03 \\
\hline & $\mathrm{T}_{2}$ & 5.32 & 5.42 & 2.60 & 3.07 & 21.90 & 22.11 \\
\hline & $\mathrm{T}_{3}$ & 4.42 & 4.55 & 2.41 & 2.56 & 19.64 & 19.18 \\
\hline & $\mathrm{T}_{4}$ & 4.18 & 4.25 & 2.38 & 2.44 & 19.00 & 17.73 \\
\hline \multirow{4}{*}{$50 \%$} & $\mathrm{~T}_{1}$ & 5.50 & 5.73 & 3.18 & 3.28 & 23.10 & 24.07 \\
\hline & $\mathrm{T}_{2}$ & 5.58 & 5.83 & 3.29 & 3.41 & 25.31 & 26.08 \\
\hline & $\mathrm{T}_{3}$ & 5.29 & 5.39 & 2.57 & 2.92 & 20.95 & 21.01 \\
\hline & $\mathrm{T}_{4}$ & 4.63 & 5.04 & 2.42 & 2.64 & 20.39 & 20.88 \\
\hline \multirow{4}{*}{$75 \%$} & $\mathrm{~T}_{1}$ & 5.96 & 6.03 & 3.48 & 3.51 & 26.51 & 27.21 \\
\hline & $\mathrm{T}_{2}$ & 6.11 & 6.22 & 3.62 & 3.69 & 27.99 & 28.43 \\
\hline & $\mathrm{T}_{3}$ & 5.37 & 5.51 & 3.07 & 3.22 & 22.60 & 24.01 \\
\hline & $\mathrm{T}_{4}$ & 5.34 & 5.47 & 2.99 & 3.19 & 22.00 & 23.96 \\
\hline \multicolumn{2}{|c|}{ LSD at 0.05} & 0.41 & 0.36 & 0.21 & 0.12 & 1.80 & 1.80 \\
\hline
\end{tabular}

${ }^{*} \mathrm{~T}_{1}$ : Plant cover, $\mathrm{T}_{2}$ : Plastic cover, $\mathrm{T}_{3}$ : Gravel cover and $\mathrm{T}_{4}$ : Control (without any cover).

Furthermore, soil mulching treatments, which used in this study had also significant effect on the same fruit parameters, mentioned before, in both seasons. It was clearly noticed that fruit length, diameter and size were the highest with plastic cover $\left(T_{2}\right)$ comparing with other treatments used. The 
data recorded form other treatments take a descending order as follows: $T_{1}$, $T_{3}$ and $T_{4}$ in both seasons in respect to fruit length, diameter and size. The data obtained from the interaction between soil moisture depletion and soil mulching treatments showed that $\mathrm{T}_{2}$ at $75 \%$ soil moisture depletion gave the highest fruit length, fruit diameter and fruit size comparing with other interactions used in the two seasons.

Generally, El-Mardi et al. (2007) on date palm are parallel with our results concerning mulching effect. They noticed that mulch increased date palm fruit length, diameter and fruit size.

\section{Fruit and bulb weights:}

Data presented in Table 6 revealed that bulb and fruit weights were significantly affected by the soil moisture depletion in both seasons. Whereas, seed weight was not significantly affected by soil moisture depletion in both seasons, therefore its data was neglected. However, soil moisture depletion at $75 \%$ increased fruit and bulb weights comparing with other soil moisture depletion ( $50 \%$ and $25 \%$ respectively). Also, soil mulching significantly affected the same fruit parameters mentioned before in both seasons. Plastic cover $\left(\mathrm{T}_{2}\right)$ had the highest ability for increasing fruit and bulb weights comparing with other treatments used. The highest fruit and bulb weights were recorded by $T_{2}$ followed by $T_{1}$ (plant cover), $T_{3}$ (gravel cover) and $\mathrm{T}_{4}$ (control treatment) in both seasons, respectively

Table 6. Effect of soil moisture depletion and soil mulching treatments on fruit and bulb weights (g) of Zaghloul date palm during 2005 and 2006 seasons.

\begin{tabular}{|c|c|c|c|c|c|}
\hline \multirow{2}{*}{\multicolumn{2}{|c|}{ Treatments }} & \multicolumn{2}{|c|}{ Fruit weight (g) } & \multicolumn{2}{|c|}{ Bulb weight (g) } \\
\hline & & 2005 & 2006 & 2005 & 2006 \\
\hline \multicolumn{6}{|c|}{ Soil moisture depletion } \\
\hline \multicolumn{2}{|c|}{$25 \%$} & 20.37 & 20.07 & 18.58 & 18.36 \\
\hline \multicolumn{2}{|c|}{$50 \%$} & 23.83 & 24.37 & 22.20 & 22.83 \\
\hline \multicolumn{2}{|l|}{$75 \%$} & 25.69 & 26.38 & 24.29 & 24.95 \\
\hline \multicolumn{2}{|c|}{ LSD at 0.05} & 0.86 & 0.86 & 0.56 & 0.60 \\
\hline \multicolumn{6}{|c|}{ Soil mulching treatments ${ }^{*}$} \\
\hline \multicolumn{2}{|l|}{$\mathrm{T}_{1}$} & 23.69 & 24.51 & 22.10 & 22.97 \\
\hline \multicolumn{2}{|l|}{$\mathrm{T}_{2}$} & 26.22 & 26.44 & 24.73 & 25.02 \\
\hline \multicolumn{2}{|l|}{$\mathrm{T}_{3}$} & 22.13 & 22.28 & 20.53 & 20.68 \\
\hline \multicolumn{2}{|l|}{$T_{4}$} & 21.16 & 21.20 & 19.41 & 19.52 \\
\hline \multicolumn{2}{|c|}{ LSD at 0.05} & 1.22 & 1.60 & 0.49 & 0.50 \\
\hline \multicolumn{6}{|c|}{ Interactions } \\
\hline \multirow{4}{*}{$25 \%$} & $\mathrm{~T}_{1}$ & 18.92 & 18.69 & 17.08 & 16.93 \\
\hline & $\mathrm{T}_{2}$ & 23.63 & 23.17 & 21.99 & 21.64 \\
\hline & $\mathrm{T}_{3}$ & 20.45 & 20.14 & 18.63 & 18.42 \\
\hline & $\mathrm{T}_{4}$ & 18.48 & 18.27 & 16.62 & 16.46 \\
\hline \multirow{4}{*}{$50 \%$} & $\mathrm{~T}_{1}$ & 24.62 & 26.55 & 23.12 & 25.09 \\
\hline & $\mathrm{T}_{2}$ & 26.41 & 27.11 & 24.94 & 25.69 \\
\hline & $\mathrm{T}_{3}$ & 22.78 & 22.50 & 21.04 & 20.93 \\
\hline & $\mathrm{T}_{4}$ & 21.51 & 21.31 & 19.69 & 19.61 \\
\hline \multirow{4}{*}{$75 \%$} & $\mathrm{~T}_{1}$ & 27.53 & 28.28 & 26.09 & 26.90 \\
\hline & $\mathrm{T}_{2}$ & 28.62 & 29.03 & 27.26 & 27.72 \\
\hline & $\mathrm{T}_{3}$ & 23.15 & 24.19 & 21.91 & 22.70 \\
\hline & $\mathrm{T}_{4}$ & 23.48 & 24.03 & 21.91 & 22.48 \\
\hline \multicolumn{2}{|c|}{ LSD at 0.05} & 2.12 & 2.77 & 0.85 & 0.90 \\
\hline
\end{tabular}

${ }^{*} \mathrm{~T}_{1}$ : Plant cover, $\mathrm{T}_{2}$ : Plastic cover, $\mathrm{T}_{3}$ : Gravel cover and $\mathrm{T}_{4:}$ Control (without any cover). 


\section{El-Kosary, S. et al.}

The interaction between soil moisture depletion and soil mulching treatments showed that $\mathrm{T}_{2}$ with soil moisture depletion at $75 \%$ was the best interaction comparing with other interactions used for producing the highest fruit and bulb weights (Table 6). On the oboist, $\mathrm{T}_{4}$ with soil moisture depletion at $25 \%$ recorded the lowest fruit weight and bulb weight in the two seasons.

The aforementioned results are disagree with results reported by Aziz (2007), who recorded that the highest fruit weight and size of date palm were obtained by $50 \%$ depletion from available water. On the other hand, Nassar et al. (2003) showed that fresh weight in date palm fruit increased as the irrigation levels increased. Ghosh and Bauri (2003) recorded that mulching increased fruit weight, which was highest by black polyethylene mulching in mango cv. Himsagar. In addition, Shirgure et al. (2003) screened that the highest fruit weight was obtained with black polyethylene mulch on Nagpur mandarin (C. reticulata).

\section{Moisture content and total soluble solids (TSS):}

Fruit moisture content and fruit total soluble solids were significantly affected by soil moisture depletion in both seasons (Table 7). However, soil moisture depletion at $75 \%$ decreased all recorded data on fruit moisture content and increased fruit content of total soluble solids comparing with other soil moisture depletion used in this study.

Table 7. Effect of soil moisture depletion and soil mulching treatments on fruit moisture content (\%) and TSS (\%) of Zaghloul date palm cultivar during 2005 and 2006 seasons.

\begin{tabular}{|c|c|c|c|c|c|}
\hline & \multirow{2}{*}{ Treatments } & \multicolumn{2}{|c|}{ Moisture content (\%) } & \multicolumn{2}{|c|}{ TSS (\%) } \\
\hline & & 2005 & 2006 & 2005 & 2006 \\
\hline \multicolumn{6}{|c|}{ Soil moisture depletion } \\
\hline \multicolumn{2}{|c|}{$25 \%$} & 67.64 & 69.07 & 29.82 & 30.75 \\
\hline \multicolumn{2}{|l|}{$50 \%$} & 62.52 & 62.96 & 31.98 & 32.54 \\
\hline \multicolumn{2}{|l|}{$75 \%$} & 59.29 & 60.35 & 33.22 & 33.62 \\
\hline \multicolumn{2}{|c|}{ LSD at 0.05} & 0.45 & 0.48 & 0.50 & 0.54 \\
\hline \multicolumn{6}{|c|}{ Soil mulching treatments* } \\
\hline \multicolumn{2}{|c|}{$\mathrm{T}_{1}$} & 62.46 & 62.82 & 32.17 & 32.83 \\
\hline \multicolumn{2}{|l|}{$\mathrm{T}_{2}$} & 59.51 & 61.69 & 33.16 & 33.62 \\
\hline \multicolumn{2}{|l|}{$\mathrm{T}_{3}$} & 63.92 & 64.68 & 31.00 & 31.69 \\
\hline \multicolumn{2}{|l|}{$\mathrm{T}_{4}$} & 66.72 & 67.32 & 30.37 & 31.08 \\
\hline \multicolumn{2}{|c|}{ LSD at 0.05} & 0.32 & 0.47 & 0.66 & 0.53 \\
\hline \multicolumn{6}{|c|}{ Interactions } \\
\hline \multirow{4}{*}{$25 \%$} & $\mathrm{~T}_{1}$ & 69.58 & 69.65 & 29.19 & 30.73 \\
\hline & $\mathrm{T}_{2}$ & 62.25 & 66.55 & 30.99 & 31.55 \\
\hline & $\mathrm{T}_{3}$ & 68.41 & 68.95 & 30.12 & 30.80 \\
\hline & $\mathrm{T}_{4}$ & 70.32 & 71.13 & 28.97 & 29.93 \\
\hline \multirow{4}{*}{$50 \%$} & $\mathrm{~T}_{1}$ & 59.96 & 60.05 & 33.14 & 33.21 \\
\hline & $\mathrm{T}_{2}$ & 58.87 & 59.89 & 33.54 & 33.87 \\
\hline & $\mathrm{T}_{3}$ & 63.31 & 64.07 & 30.93 & 31.70 \\
\hline & $\mathrm{T}_{4}$ & 67.94 & 67.84 & 30.33 & 31.36 \\
\hline \multirow{4}{*}{$75 \%$} & $\mathrm{~T}_{1}$ & 57.84 & 58.78 & 34.18 & 34.54 \\
\hline & $\mathrm{T}_{2}$ & 57.40 & 58.62 & 34.95 & 35.43 \\
\hline & $\mathrm{T}_{3}$ & 60.04 & 61.03 & 31.94 & 32.57 \\
\hline & $\mathrm{T}_{4}$ & 61.89 & 62.98 & 31.81 & 31.94 \\
\hline \multicolumn{2}{|c|}{ LSD at 0.05} & 0.55 & 0.82 & 1.15 & 0.92 \\
\hline
\end{tabular}

${ }^{*} \mathrm{~T}_{1}$ : Plant cover, $\mathrm{T}_{2}$ : Plastic cover, $\mathrm{T}_{3}$ : Gravel cover and $\mathrm{T}_{4}$ : Control (without any cover) 
Furthermore, soil mulching treatments, which used in this study, had also significant effect on Zaghloul fruit moisture and TSS content in both seasons. Fruit moisture was the lowest with plastic cover $\left(T_{2}\right)$ which showed the highest level of TSS comparing with other treatments used. In this respect, control produced the highest fruit moisture and the lowest TSS contents in both seasons.

The interaction between soil moisture depletion and soil mulching treatments showed that $\mathrm{T}_{2}$ with soil moisture depletion at $75 \%$ decreased the percentages of moisture and increased TSS fruit content comparing with other interactions used. Whereas, $\mathrm{T}_{4}$ with $25 \%$ soil moisture depletion recorded the highest fruit moisture content and the lowest TSS in both seasons.

These results are in agreement with data recorded by Alihouri (2007), who recorded that irrigation intervals had affected significantly moisture and TSS of date palm fruits.

\section{Zaghloul fruit content of total acidity and tannins:}

Zaghloul date palm fruit content of total acidity was insignificantly affected by the soil moisture depletion in both seasons. While, fruit tannins content was significantly affected by different treatments in both seasons (Table 8).

Table 8. Effect of soil moisture depletion and soil mulching treatments on total acidity (\%) and tannins content (\%) of Zaghloul date palm during 2005 and 2006 seasons.

\begin{tabular}{|c|c|c|c|c|c|}
\hline \multirow{2}{*}{\multicolumn{2}{|c|}{ Treatments }} & \multicolumn{2}{|c|}{ Total acidity (\%) } & \multicolumn{2}{|c|}{ Tannins content (\%) } \\
\hline & & 2005 & 2006 & 2005 & 2006 \\
\hline \multicolumn{6}{|c|}{ Soil moisture depletion } \\
\hline \multicolumn{2}{|c|}{$25 \%$} & 0.02 & 0.02 & 0.29 & 0.30 \\
\hline \multicolumn{2}{|l|}{$50 \%$} & 0.01 & 0.02 & 0.25 & 0.26 \\
\hline \multicolumn{2}{|l|}{$75 \%$} & 0.01 & 0.01 & 0.21 & 0.23 \\
\hline \multicolumn{2}{|c|}{ LSD at 0.05} & NS & NS & 0.03 & 0.05 \\
\hline \multicolumn{6}{|c|}{ Soil mulching treatments* } \\
\hline \multicolumn{2}{|c|}{$\mathrm{T}_{1}$} & 0.01 & 0.01 & 0.24 & 0.25 \\
\hline \multicolumn{2}{|l|}{$\mathrm{T}_{2}$} & 0.01 & 0.01 & 0.21 & 0.23 \\
\hline \multicolumn{2}{|l|}{$\mathrm{T}_{3}$} & 0.02 & 0.02 & 0.27 & 0.28 \\
\hline \multicolumn{2}{|l|}{$\mathrm{T}_{4}$} & 0.02 & 0.02 & 0.28 & 0.30 \\
\hline \multicolumn{2}{|c|}{ LSD at 0.05} & NS & NS & 0.04 & 0.04 \\
\hline \multicolumn{6}{|c|}{ Interactions } \\
\hline \multirow{4}{*}{$25 \%$} & $\mathrm{~T}_{1}$ & 0.02 & 0.02 & 0.29 & 0.31 \\
\hline & $\mathrm{T}_{2}$ & 0.01 & 0.02 & 0.27 & 0.28 \\
\hline & $\mathrm{T}_{3}$ & 0.02 & 0.02 & 0.29 & 0.30 \\
\hline & $\mathrm{T}_{4}$ & 0.02 & 0.03 & 0.29 & 0.32 \\
\hline \multirow{4}{*}{$50 \%$} & $\mathrm{~T}_{1}$ & 0.01 & 0.01 & 0.23 & 0.24 \\
\hline & $\mathrm{T}_{2}$ & 0.01 & 0.01 & 0.20 & 0.21 \\
\hline & $\mathrm{T}_{3}$ & 0.01 & 0.02 & 0.28 & 0.29 \\
\hline & $\mathrm{T}_{4}$ & 0.02 & 0.02 & 0.28 & 0.29 \\
\hline \multirow{4}{*}{$75 \%$} & $\mathrm{~T}_{1}$ & 0.01 & 0.01 & 0.19 & 0.20 \\
\hline & $\mathrm{T}_{2}$ & 0.01 & 0.01 & 0.17 & 0.19 \\
\hline & $\mathrm{T}_{3}$ & 0.02 & 0.02 & 0.23 & 0.25 \\
\hline & $\mathrm{T}_{4}$ & 0.01 & 0.01 & 0.26 & 0.28 \\
\hline \multicolumn{2}{|c|}{ LSD at 0.05} & NS & NS & 0.07 & 0.07 \\
\hline
\end{tabular}

${ }^{*} \mathrm{~T}_{1}$ : Plant cover, $\mathrm{T}_{2:}$ Plastic cover, $\mathrm{T}_{3}$ : Gravel cover and $\mathrm{T}_{4:}$ Control (without any cover) 
However, soil moisture depletion at $25 \%$ recorded increasing in fruit tannins as compared with soil moisture depletion in descending order at $50 \%$ and $75 \%$ in both seasons.

Regarding to soil mulching treatments, total acidity was insignificantly affected by the different soil mulching treatments used in both seasons. However, $\mathrm{T}_{4}$ treatment produce the highest tannins fruit content followed by $T_{3}, T_{1}$ and $T_{2}$ in both seasons, respectively.

The data obtained from the interaction between soil moisture depletion and soil mulching treatments showed that fruit total acidity was insignificantly affected by different interactions used in both seasons. On the other hand, fruit tannins content was affected significantly by different interactions between soil moisture depletion and soil mulching treatments in both seasons. Whatever, the interaction between $25 \%$ depletion with $T_{1}, T_{3}$ and $T_{4}$ in the first season and $T_{4}$ in the second season recorded the highest content of tannins comparing to other interactions.

The obtained results are parallel with results of Alihouri (2007) who stated the effect of irrigation interval on total acid of fresh weight as it was significantly differed in date palm fruits. Mohanty et al. (2002) screened that mulching with polyethylene sheet decreased acidity in mandarin orchard. On the other hand, Ghosh and Bauri (2003) recorded that fruit acidity was not affected by various mulching treatments in mango cv. Himsagar.

\section{Zaghloul fruit content of total and reducing sugars:}

Fruit total soluble sugars and reducing sugars contents were affected significantly by different soil moisture depletion in both seasons (Table 9). Soil moisture depletion at $75 \%$ recorded the highest fruit total and reducing sugars contents followed by soil moisture depletion at $50 \%$ and $25 \%$ in both seasons, respectively.

Furthermore, soil mulching treatments had also significant effect on total and reducing sugars in both season. It was clearly noticed that fruit total and reducing sugars contents were the highest with plastic cover $\left(T_{2}\right)$ comparing with other treatments used. Moreover, the lowest total and reducing sugars was obtained when palms were treated by $\mathrm{T}_{4}$ in both seasons.

The data obtained from the interaction between soil moisture depletion and soil mulching treatments showed that $T_{2}$ with soil moisture depletion at $75 \%$ was the best interaction comparing with other interactions used to produce the highest fruit total and reducing sugars content.

These results are parallel with data recorded by Alihouri (2007), who recorded the significant effect of irrigation interval on total sugars of fresh fruit of date palm. Ghosh and Bauri (2003) found that the highest total sugar contents were recorded under black polyethylene mulch in mango cv. Himsagar. 
Table 9. Effect of soil moisture depletion and soil mulching treatments on total and reducing sugars (\%) content of Zaghloul date palm fruits during 2005 and 2006 seasons.

\begin{tabular}{|c|c|c|c|c|c|}
\hline \multirow{2}{*}{\multicolumn{2}{|c|}{ Treatments }} & \multicolumn{2}{|c|}{ Total sugars (\%) } & \multicolumn{2}{|c|}{ Reducing sugars (\%) } \\
\hline & & 2005 & 2006 & 2005 & 2006 \\
\hline \multicolumn{6}{|c|}{ Soil moisture depletion } \\
\hline \multicolumn{2}{|c|}{$25 \%$} & 52.44 & 54.22 & 49.91 & 52.15 \\
\hline \multicolumn{2}{|l|}{$50 \%$} & 58.58 & 59.82 & 56.11 & 57.63 \\
\hline \multicolumn{2}{|l|}{$75 \%$} & 61.20 & 63.30 & 58.91 & 60.97 \\
\hline \multicolumn{2}{|c|}{ LSD at 0.05} & 0.47 & 0.60 & 0.37 & 0.36 \\
\hline \multicolumn{6}{|c|}{ Soil mulching treatments ${ }^{*}$} \\
\hline \multicolumn{2}{|l|}{$\mathrm{T}_{1}$} & 58.93 & 60.81 & 56.82 & 58.50 \\
\hline \multicolumn{2}{|l|}{$\mathrm{T}_{2}$} & 61.88 & 62.76 & 59.57 & 60.79 \\
\hline \multicolumn{2}{|l|}{$\mathrm{T}_{3}$} & 55.36 & 57.58 & 52.81 & 55.39 \\
\hline \multicolumn{2}{|l|}{$\mathrm{T}_{4}$} & 53.44 & 55.30 & 50.70 & 52.97 \\
\hline \multicolumn{2}{|c|}{ LSD at 0.05} & 0.64 & 0.51 & 0.62 & 0.57 \\
\hline \multicolumn{6}{|c|}{ Interactions } \\
\hline \multirow{4}{*}{$25 \%$} & $\mathrm{~T}_{1}$ & 50.37 & 53.07 & 48.31 & 51.10 \\
\hline & $\mathrm{T}_{2}$ & 56.29 & 58.21 & 53.46 & 56.23 \\
\hline & $\mathrm{T}_{3}$ & 53.58 & 54.90 & 51.08 & 52.84 \\
\hline & $\mathrm{T}_{4}$ & 49.51 & 50.69 & 46.78 & 48.41 \\
\hline \multirow{4}{*}{$50 \%$} & $\mathrm{~T}_{1}$ & 61.17 & 62.61 & 58.88 & 60.33 \\
\hline & $\mathrm{T}_{2}$ & 63.10 & 63.04 & 61.06 & 61.03 \\
\hline & $\mathrm{T}_{3}$ & 55.40 & 57.27 & 52.81 & 55.07 \\
\hline & $\mathrm{T}_{4}$ & 54.65 & 56.34 & 51.67 & 54.09 \\
\hline \multirow{4}{*}{$75 \%$} & $\mathrm{~T}_{1}$ & 65.25 & 66.75 & 63.27 & 64.08 \\
\hline & $\mathrm{T}_{2}$ & 66.26 & 67.02 & 64.18 & 65.10 \\
\hline & $\mathrm{T}_{3}$ & 57.10 & 60.57 & 54.55 & 58.27 \\
\hline & $\mathrm{T}_{4}$ & 56.17 & 58.87 & 53.65 & 56.41 \\
\hline \multicolumn{2}{|c|}{ LSD at 0.05} & 1.12 & 0.89 & 0.39 & 0.99 \\
\hline
\end{tabular}

${ }^{*} \mathrm{~T}_{1}$ : Plant cover, $\mathrm{T}_{2}$ : Plastic cover, $\mathrm{T}_{3}$ : Gravel cover and $\mathrm{T}_{4:}$ Control (without any cover)

\section{Total applied and number of irrigation water:}

Data presented in Table 10 revealed that total applied irrigation water was not significantly affected by soil moisture depletion in both seasons. While, total number of irrigation was significantly affected by soil moisture depletion in both seasons. However, soil moisture depletion at $25 \%$ recorded the highest total number of irrigation as compared with other depletion used.

Regarding to soil mulching treatments, total applied irrigation water and total number of irrigation were significantly affected by the different soil mulching treatments used in both seasons. It was clearly noticed that total applied irrigation water and its number were the lowest with plastic cover $\left(T_{2}\right)$ comparing with other treatments used.

The data obtained from the interaction between soil moisture depletion and soil mulching treatments showed that $\mathrm{T}_{2}$ irrigated by either $25 \%$ or $50 \%$ or $75 \%$ soil moisture depletion was the best interaction to decrease total applied irrigation water in both seasons comparing with other interactions used. However, $\mathrm{T}_{2}$ irrigated by $75 \%$ soil moisture depletion reduced the number of irrigation in both seasons comparing with other interactions used.

These results are parallel to results recorded by Hussain et al. (1993) and Nassar et al. (2003), who mentioned that irrigation at 40-60\% 
depletion of the total available water, would be adequate for date palm production with minimum adverse effect on date fruit quality and quantity. The total consumptive use of water was increased by irrigation at shorter intervals compared to less frequent irrigation.

Table 10. Effect of soil moisture depletion and soil mulching treatments on total applied $\left(\mathrm{m}^{3}\right)$ and number of irrigation water of Zaghloul date palm during 2005 and 2006 seasons.

\begin{tabular}{|c|c|c|c|c|c|}
\hline \multirow{2}{*}{\multicolumn{2}{|c|}{ Treatments }} & \multicolumn{2}{|c|}{$\begin{array}{c}\text { Total applied irrigation water } \\
\left(\mathrm{m}^{3} / \text { palm/year) }\right.\end{array}$} & \multicolumn{2}{|c|}{$\begin{array}{c}\text { Total number of } \\
\text { irrigation/palm/year) }\end{array}$} \\
\hline & & 2005 & 2006 & 2005 & 2006 \\
\hline \multicolumn{6}{|c|}{ Soil moisture depletion } \\
\hline \multicolumn{2}{|c|}{$25 \%$} & 116.70 & 97.20 & 583.25 & 583.25 \\
\hline \multicolumn{2}{|l|}{$50 \%$} & 117.00 & 97.50 & 390.00 & 390.00 \\
\hline \multicolumn{2}{|l|}{$75 \%$} & 117.80 & 98.16 & 294.50 & 294.50 \\
\hline \multicolumn{2}{|c|}{ LSD at 0.05} & NS & NS & 0.82 & 0.82 \\
\hline \multicolumn{6}{|c|}{ Soil mulching treatments* } \\
\hline \multicolumn{2}{|c|}{$\mathrm{T}_{1}$} & 118.43 & 98.69 & 427.33 & 427.33 \\
\hline \multicolumn{2}{|l|}{$\mathrm{T}_{2}$} & 73.33 & 61.10 & 264.33 & 264.33 \\
\hline \multicolumn{2}{|l|}{$\mathrm{T}_{3}$} & 130.27 & 108.50 & 469.67 & 469.67 \\
\hline \multicolumn{2}{|l|}{$\mathrm{T}_{4}$} & 146.63 & 113.82 & 529.00 & 529.00 \\
\hline \multicolumn{2}{|c|}{ LSD at 0.05} & 0.79 & 0.80 & 0.79 & 0.79 \\
\hline \multicolumn{6}{|c|}{ Interactions } \\
\hline \multirow{4}{*}{$25 \%$} & $\mathrm{~T}_{1}$ & 118.0 & 98.33 & 590.00 & 590.00 \\
\hline & $\mathrm{T}_{2}$ & 72.80 & 60.66 & 364.00 & 364.00 \\
\hline & $\mathrm{T}_{3}$ & 129.80 & 108.00 & 648.00 & 648.00 \\
\hline & $\mathrm{T}_{4}$ & 146.20 & 121.83 & 731.00 & 731.00 \\
\hline \multirow{4}{*}{$50 \%$} & $\mathrm{~T}_{1}$ & 118.50 & 98.75 & 395.00 & 395.00 \\
\hline & $\mathrm{T}_{2}$ & 73.20 & 61.00 & 244.00 & 244.00 \\
\hline & $\mathrm{T}_{3}$ & 130.20 & 108.50 & 434.00 & 434.00 \\
\hline & $\mathrm{T}_{4}$ & 146.10 & 121.75 & 487.00 & 487.00 \\
\hline \multirow{4}{*}{$75 \%$} & $\mathrm{~T}_{1}$ & 118.80 & 99.00 & 297.00 & 297.00 \\
\hline & $\mathrm{T}_{2}$ & 74.00 & 61.66 & 185.00 & 185.00 \\
\hline & $\mathrm{T}_{3}$ & 130.80 & 109.00 & 327.00 & 327.00 \\
\hline & $\mathrm{T}_{4}$ & 147.60 & 123.00 & 369.00 & 369.00 \\
\hline \multicolumn{2}{|c|}{ LSD at 0.05} & 1.58 & 1.59 & 1.58 & 1.58 \\
\hline
\end{tabular}

${ }^{\star} \mathrm{T}_{1}$ : Plant cover, $\mathrm{T}_{2:}$ Plastic cover, $\mathrm{T}_{3}$ : Gravel cover and $\mathrm{T}_{4}$ : Control (without any cover)

\section{Water use efficiency:}

Table 11, showed that water use efficiency of Zaghloul date palm was insignificantly affected by the soil moisture depletion in both seasons. However, soil moisture depletion at $25 \%$ recorded increasing in water use efficiency as compared with other depletion used.

Regarding to soil mulching treatments, water use efficiency was significantly affected by the different soil mulching treatments used in both seasons. It was clearly noticed that water use efficiency was the highest with plastic cover $\left(\mathrm{T}_{2}\right)$ comparing with other treatments used.

The interaction between soil moisture depletion and soil mulching treatments showed that $\mathrm{T}_{2}$ with $25 \%, 50 \%$ and $75 \%$ soil moisture depletion was the best treatments for increasing water use efficiency. On the other hand, $\mathrm{T}_{4}$ (untreated soil surface) with $25 \%, 50 \%$ and $75 \%$ soil moisture depletions decreased water use efficiency. 
Table 11. Effect of soil moisture depletion and soil mulching treatments on water use efficiency $\mathrm{kg} / \mathrm{m}^{3}$ of Zaghloul date palm during 2005 and 2006 seasons.

\begin{tabular}{|c|c|c|c|}
\hline \multirow{2}{*}{\multicolumn{2}{|c|}{ Treatments }} & \multicolumn{2}{|c|}{ Water use efficiency $\left(\mathrm{kg} / \mathrm{m}^{3}\right)$} \\
\hline & & 2005 & 2006 \\
\hline \multicolumn{4}{|c|}{ Soil moisture depletion } \\
\hline \multicolumn{2}{|c|}{$25 \%$} & 1.13 & 1.35 \\
\hline \multicolumn{2}{|l|}{$50 \%$} & 1.10 & 1.31 \\
\hline \multicolumn{2}{|l|}{$75 \%$} & 1.08 & 1.29 \\
\hline \multicolumn{2}{|c|}{ LSD at 0.05} & NS & NS \\
\hline \multicolumn{4}{|c|}{ Soil mulching treatments* } \\
\hline \multicolumn{2}{|l|}{$\mathrm{T}_{1}$} & 1.02 & 1.22 \\
\hline \multicolumn{2}{|l|}{$\mathrm{T}_{2}$} & 1.65 & 1.98 \\
\hline \multicolumn{2}{|l|}{$\mathrm{T}_{3}$} & 0.92 & 1.09 \\
\hline \multicolumn{2}{|l|}{$\mathrm{T}_{4}$} & 0.82 & 0.97 \\
\hline \multicolumn{2}{|c|}{ LSD at 0.05} & 0.25 & 0.36 \\
\hline \multicolumn{4}{|c|}{ Interactions } \\
\hline \multirow{4}{*}{$25 \%$} & $\mathrm{~T}_{1}$ & 1.05 & 1.25 \\
\hline & $\mathrm{T}_{2}$ & 1.71 & 2.05 \\
\hline & $T_{3}$ & 0.94 & 1.12 \\
\hline & $\mathrm{T}_{4}$ & 0.83 & 0.98 \\
\hline \multirow{4}{*}{$50 \%$} & $T_{1}$ & 1.02 & 1.22 \\
\hline & $\mathrm{T}_{2}$ & 1.64 & 1.96 \\
\hline & $\mathrm{T}_{3}$ & 0.92 & 1.09 \\
\hline & $\mathrm{T}_{4}$ & 0.82 & 0.98 \\
\hline \multirow{4}{*}{$75 \%$} & $T_{1}$ & 0.99 & 1.19 \\
\hline & $\mathrm{T}_{2}$ & 1.63 & 1.94 \\
\hline & $\mathrm{T}_{3}$ & 0.89 & 1.07 \\
\hline & $\mathrm{T}_{4}$ & 0.82 & 0.96 \\
\hline \multicolumn{2}{|c|}{ LSD at 0.05} & 0.44 & 0.63 \\
\hline
\end{tabular}

${ }^{\star} \mathrm{T}_{1}$ : Plant cover, $\mathrm{T}_{2}$ : Plastic cover, $\mathrm{T}_{3}$ : Gravel cover and $\mathrm{T}_{4:}$ Control (without any cover)

Generally, these results are in agreement with data recorded by AlAmoud et al. (2000), who found that water use efficiency was the maximum for $150 \%$ from evapotranspiration "ETo", $100 \%$ and $50 \%$ from evapotranspiration "ETo" of Seleg date palm cultivar. In addition, Aziz (2007) showed that highest water use efficiency was $50 \%$ depletion from available water of date palm Sewy variety. Sayed et al. (2007) found that highest water use efficiency was 1 from evapotranspiration "Etc for Sewy date palm.

From the above results, it was clearly noticed that using soil moisture depletion at $25 \%$ produced the highest fruit set percentage, total yield and fruit content of tannins. It may be due to late fruit ripening in response to sufficient watering irrigation (Furr and Armstromg, 1956 and Hussein and Hussein, 1983). On the other hand, Soil moisture depletion at $75 \%$ produced the highest fruit quality (length, diameter, size, weight, bulb weight and TSS). In addition, it increased fruit content of (total and reducing sugars). In respect to soil treatments, $\mathrm{T}_{2}$ (plastic cover) had increased the most of the studied parameters. Also, the interaction between depletion and soil mulching treatments reflected that interaction between $\mathrm{T}_{2}$ and $25 \%$ depletion increased fruit set percentage and total yield comparing with other interactions used. Whereas, the interaction between $\mathrm{T}_{2}$ and $75 \%$ depletion improved all fruit characters and fruit content that studied in this research. 


\section{El-Kosary, S. et al.}

The improvement of the studied fruit characteristics (fruit length, diameter, size, fruit and pulp weights, TSS and sugars contents) which was obtained by depletion at $75 \%$ as well as its interaction with plastic mulching may be partially attributed to its reduction effects on fruit setting and yield compared with depletion at $25 \%$. Regarding to water use efficiency, it had increased with $25 \%$ depletion than 50 and $75 \%$ in both seasons. Also, $\mathrm{T}_{2}$ and interaction between $\mathrm{T}_{2}$ and $75 \%$ depletion produced the highest record of parameters mentioned before. In addition, using $\mathrm{T}_{2}$ with $75 \%$ depletion produced the lowest total applied irrigation water and total number of irrigation. So, we can concluded that covering soil by plastic sheets under palm tree and using deep irrigation method with long period intervals between irrigation improved fruit characteristics.

\section{REFERENCES}

Al-Amoud, A. I.; M.A. Bacha; and A. M. Al-Darby (2000). Seasonal water use of date palms in the central region of Saudi Arabia. International Agricultural Engineering Journal, 9 (2): 51-62.

Alihouri, M (2007) Effect of irrigation interval during flowering and fruit set stage on the yield of date palm cv. Barhee. Proc. Of The Fourth Symp. On Date Palm, Saudi Arabia, King Faisal Univ., Al-Hassa, 5-8 May, pp 63.

Ali, M. Y. M. (2008). Effect of fertilization, irrigation and planting distances on the growth and production of Origanum syriacum L. plant under Sinai conditions. Ph.D. Thesis, Ornamental Hort., Fac. Agric., Cairo Univ., Egypt, pp. 130.

Al-Wasel, A. S.; D.A. EL-Rayes; S. AL-Thonayan and R. Abo-Ayana (2007). Effects of irrigation regime, potassium fertilizer quantity and application methods on cv. Sukarry date peeling and blackening. Proc. of The Fourth Symp. on Date Palm, Saudi Arabia, King Faisal Univ., ALHassa, 5-8 May, pp 79.

Amiri, M. E. (2003). Technical report of the quantity and quality of plants grown in the Kish Island. Landscape Office, Service and Development Co., Kish Island, Iran, pp. 127.

Amiri, M. E.; M. Panahi and G. Aghazadeh (2007). Comparison of bubbler, sprinkler and basin irrigation for date palms (Phoenix dactylifera, cv. Zahdi) growth in Kish Island, Iran. Journal of Food Agriculture and Environment Vol. 5 (3\&4): 185-187.

Association of Official Agricultural chemists (1995). Official Methods of Analysis A.O.A.C. $1^{\text {th }}$ Ed. Published by A.O.A.C. Washington, D. C. (U. S. A.).

Aziz, N. G. M. (2007). Impact of water regime and organic manure application on some characteristics of soil and date palms grown there on. Egypt. J. of Appl. Sci., 22 (3): 319-330. 
El-Mardi, M. O.; F. Al-Said; C.B. Sakit; L.M. Al-Kharusi; I.N. Al-Rahbi and K. Al-Mahrazi (2007). Effect of pollination method, fertilizer and mulch treatments on the physical and chemical characteristics of date palm (Phoenix dactylifera L.) Fruit. 1: Physical characteristics. Acta Horticulture 736: 123-131.

El-Romah, M. and M.A. Kassem (1989). The effect of irrigation intervals on the date palm yield. The International Con. on Date Palm, Saudi Arabia, King Faisal Univ., September, 16-19, 169-182.

El-Salhy, A. M. (2001). The relation between leaf/bunch ratio and Zaghloul date productivity. Egypt J. Hort., 28 (2): 149-158.

Furr, J. R. and W. W. Armstrong (1956). The seasonal use of water by Khadrawy date palms. Date Grower's Inst. Rep., 33: 5-7.

Ghosh, S. N. and F. K. Bauri (2003). Effect of mulching on yield, physical and chemical properties of mango fruits cv. Himsagar grown in rainfed laterite soils. Orissa J. Hort., 31(1): 78-81.

Hussain, G.; A. S. Al-Ghamdi; M. S. Al-Qahtani; K. Al-Bogliae and M. O. Abdul-Salam. (1993). Water requirements of date palm (phoenix dactylifera L.) in Al-Hassa, Kingdom of Saudi Arabia. Proc. of The Third Symp. On The Date Palm In Saudi Arabia King Faisal Univ., Al-Hassa March 23-25 217-230.

Hussein, F, and M. A. Hussein (1983). Effect of irrigation on growth, yield and fruit quality of dry dates at Asswan. Proc. of The First Symp.On The Date Palm In Saudi Arabia, King Faisal Univ., Al-Hassa, March 23-25, 168-173.

Jain, B. L. and O. P. Pareek (1989). Effect of drip irrigation and mulch on soil and performance of date palm under saline water irrigation. Annals of Arid Zone, 28 (3-4): 245-248.

James, G. (1988). Principles of Farm Irrigation System Design. Jon Willey \& Sons (ed.) New York, pp543.

Kashani, J. (1990). Characteristics of date cultivars in Iran. Res. Insit. of Seed and Seedling, Karaje, Iran, 51-81.

Mohamed, S. S. and Z. Khemaies (1998). Water supply, growth and yield of Deglet Nour palm trees in the Atilet Nefzaoua Experimental Station (Tunisia). Medit. 9 (4): 58-62.

Mohanty, S.; Sonkar, R. K. and Marathe, R. A. (2002). Effect of mulching on Nagpur mandarin cultivation in drought prone region of Central India. Indian J. of Soil Conservation. 30 (3): 286-289.

Nassar, I. N.; K. N. Al-Redhaiman and M. Al-Salamah (2003). Effects of irrigation water quality and quantity on the yield and yield quality of date palm. The International Con. On Date Palm, Saudi Arabia, 16-19 Sep. 122-135.

Nelson, N.; N. Somogy (1944). Colorimetric method for determination of reducing sugars related substances. J. Bio. Chem. 153: 375-379.

Norman, W. R.; W. H. Shayya; A. S. Al-Ghafri and I. R. McCann (1998). A flaj irrigation and on-farm water management in Northern Oman. Irrigation and Drainage System, 12 (1): 35-48. 


\section{El-Kosary, S. et al.}

Ranganna, S. (1979). Manual of analysis of fruit and vegetable products, $2^{\text {nd }}$ ed. Tata McGraw-Hill, Publishing Company Limited, New Delhi, pp.634.

Sayed, M. A.; M. M. El-Garawany and M. E. Morsy (2007). Water utilization efficiency for date palm at New Valley, Egypt. Proc. Of the Fourth Symp. on Date Palm, Saudi Arabia, King Faisal Univ., AL-Hassa, 5-8 May, pp 211.

Shaheen, M. A. (2007). Yield and quality of date palm Rabeeha cv. as affected by three irrigation systems. Arid Land Agric. Dept., Fac. Meteo., Envir. and Arid Land Agric., King Abdulaziz Univ., Jeddah, Saudi Arabia, 18: 23-39.

Shirgure, P. S.; R.K. Sonkar; S. Singh and P. Panigrahi (2003). Effect of different mulches on soil moisture conservation, weed reduction, growth and yield of drip irrigated Nagpur mandarin Citrus reticulate. Indian J. of Agric. Sci., 73 (3): 148-152.

Smith, F.; Gilles, M. A.; Hamilton, J. K. and Godess, P. A. (1956). Colorimetric method for determination of sugars related substances. Anal. Chem., 28: 350-356.

Snedecor, G.W. and W.G. Cochran (1989). Statistical Methods. $7^{\text {th }}$ Ed., lowa State Univ. Press. Ames. lowa, U.S.A., pp 593.

Steel, R. C. D. and J.H. Torrie (1980). Reproduced From Principles and Procedures of Statistics. Printed with the permission of C. I. Bliss, pp. 448-449.

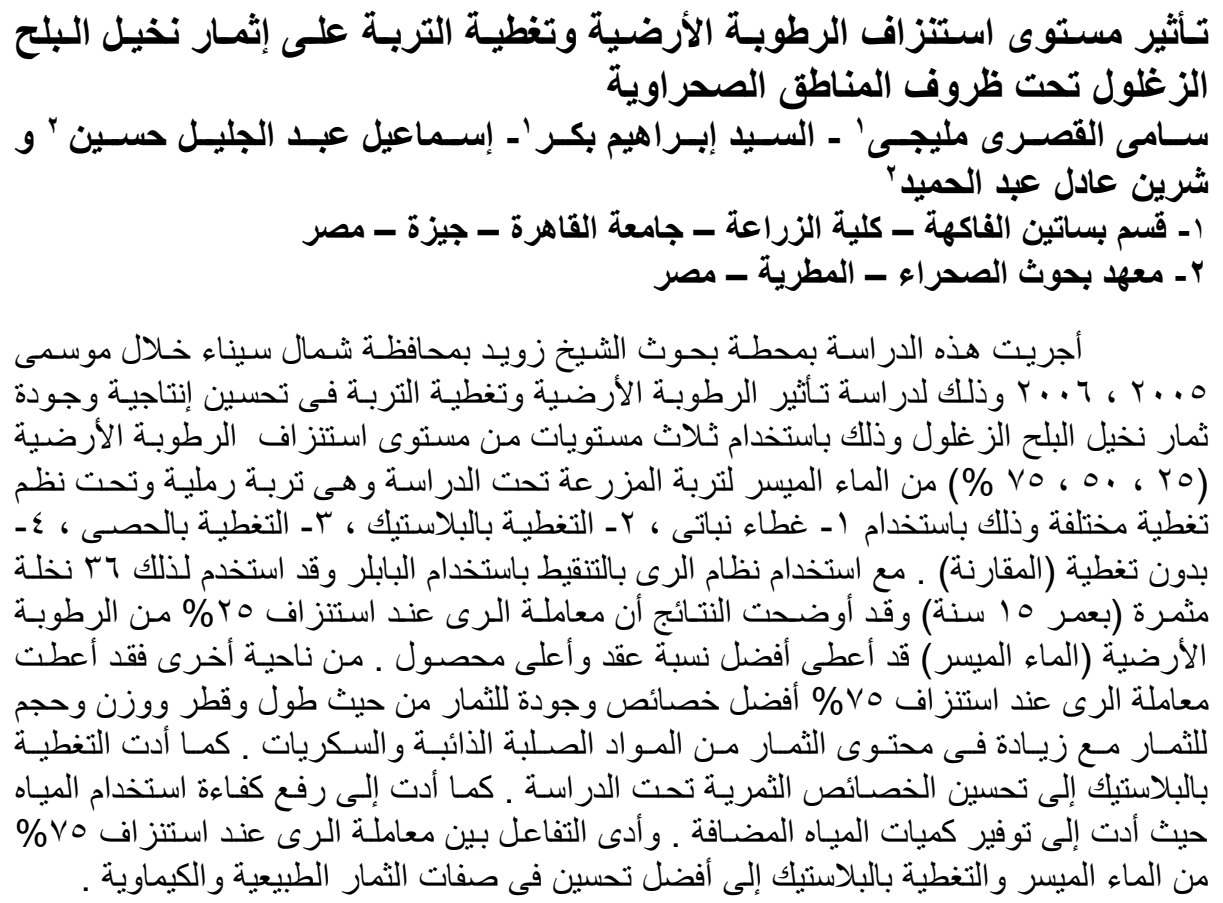

